\title{
Screening and Characterization of the Antagonistic Properties of Microorganisms Isolated From Natural Sources
}

\author{
V. M. Le, L. K. Asyakina*, N. S. Velichkovich, O. V. Kozlova, I. S. Milentyeva, A. V. Pozdnyakova, A. Y. Prosekov \\ Department of Bionanotechnology, Kemerovo State University, 6 Krasnaya Street, Kemerovo 650000, Russia
}

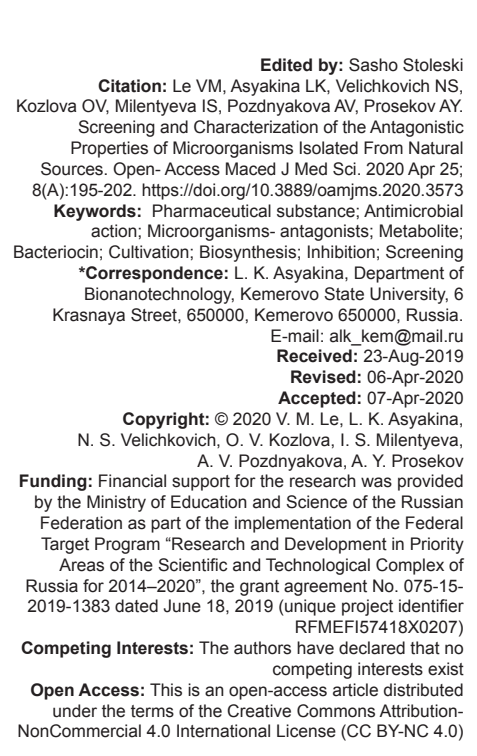

Introduction

The formation of antimicrobial resistance, such as antibiotics, antiseptics, and bacteriophages, is a natural adaptation mechanism of microorganisms and is a serious medical and social problem. Today, most clinically important pathogenic and opportunistic bacteria are able to develop resistance to antibacterial substances. There were strains of various types of microorganisms that are not sensitive to the action of almost all antibiotics used in medical practice, while the rate of obtaining new drugs has significantly decreased. In this regard, the creation of new antimicrobial agents or methods of their delivery is a priority area of biology, medicine, and veterinary medicine. Such an alternative may be bacteriocins, lowmolecular peptides, having a highly specific antibacterial effect, aimed at strains of phylogenetically related or conamed species of bacteria, delivered to the target cells by conjugative transport - a natural way of intercellular communication of prokaryotic cells [1], [2], [3].

\begin{abstract}
BACKGROUND: Human infectious diseases caused by antibiotic-resistant bacterial pathogens present a serious problem for clinical medicine. Causative agents of nosocomial infections, such as Escherichia coli, Klebsiella can effectively combat drugresistant pathogens is underway. Antimicrobial substances of bacterial origin are of
\end{abstract} from natural sources in connection with the creation of new pharmaceutical substances
fortic

METHODS: The material for the isolation of microorganisms was the soil, water bodies, and plant objects of various the methods proposed in the directory "Bergey's Manual of Determinative Bacteriology" and in the monograph Nesterenko et al. The selection of strains from soil samples was carried out according to standard methods described RESULTS: The following results are obtained: (1) Lactic acid bacteria and other microorganisms antagonists from natural sources were isolated: Soil, water bodies, and plant objects; 20 isolates were isolated, their cultural and Bacillus, Leuconostoc, Pedio-coccus, Lactobacillus, and Bacteroides; (2) Antimicrobial properties of lactic acid antagonist microorganisms isolated from natural sources, as well as other more detailed studies will be conducted with selected 12 strains with maximum antimicrobial properties.
The ability to produce bacteriocins has Gram-positive and Gram-negative bacteria. However, bacteriocins synthesized by Gram-negative bacteria have a rather narrow spectrum of action and therefore have not been widely used as strains-producers. Gram-positive bacteriocins (lactic acid bacteria) have stronger antimicrobial properties and are currently promising for the study of the possibility of various kinds of bacteriocins [4], [5], [6]. Antimicrobial activity of bacteriocins of lactic acid bacteria is directly dependent on environmental conditions (temperature, $\mathrm{pH}$ and consistency of the medium, the composition of the medium, the concentration of metals, and other factors) [7], [8].

\section{Bacteriocin Classification}

Bacteriocins are divided into four classes. Division by classes is carried out according to the 
methods of synthesis, physicochemical and amino acid composition, and antibacterial properties [9], [10].

The first class bacteriocins represent lantibiotic, low molecular weight peptides ( $<5 \mathrm{kDa})$, hydrophobic, and cationic nature [11, [12], [13], [14].

The most studied bacteriocin from the first class is nisin isolated from Lactococcus lactis. The action of nisin is based on the violation of the permeability of bacterial spores, thereby reducing their thermal stability [15], [16].

The second class of bacteriocins includes lanthionine-containing peptides of low molecular weight $(<10 \mathrm{kDa})$, resistant to temperature, and active in a wide range of $\mathrm{pH}(3-9)$. Bacteriocins of this class do not cause a high immune response and are non-toxic to both humans and animals [17, [18], [19], [20], [21].

In turn, Class II bacteriocins are divided into subclasses Ila, IIb, and Ilc depending on antimicrobial activity, methods of separation from the producing strain and chemical composition [22], [23], [24], [25], [26], [27].

Bacteriocins belonging to Class III (e.g., enterolysin A) are proteins with a high antimicrobial action and a molecular weight of more than $30 \mathrm{kDa}$, which are destroyed by high and low temperatures.

Class IV includes bacteriocins that have lipid and carbohydrate components in their composition, which gives them high activity [28], [29].

All four classes of bacteriocins in some cases have the same amino acid sequence, which allows a large number of strains of lactic acid bacteria to synthesize bacteriocins [30], [31].

\section{Mechanism of Action of Bacteriocins}

Bacteriocins affect the main functions of bacterial cells due to the huge variety of chemical structures. The action of bacteriocins is based on the change of cell membrane tension due to the formation of pores in it [32], [33].

The mechanism of pore formation in each class of bacteriocins is different [34], [35], [36].

Figure 1 shows the mechanism of action of the bacteriocin nisin. C-end of the nizin molecule reduces the potential difference in the cytoplasmic membrane and thus inhibits the development of cellular components and the action of intracellular.

Similar to nisin mechanism of action was observed in bacteriocins of Class Ila [11].

The action of bacteriocins mainly consists in the formation of pores in the cell membrane, leading to the destruction of the cell. In some cases, bacteriocins prevent cell wall formation [8]. Different

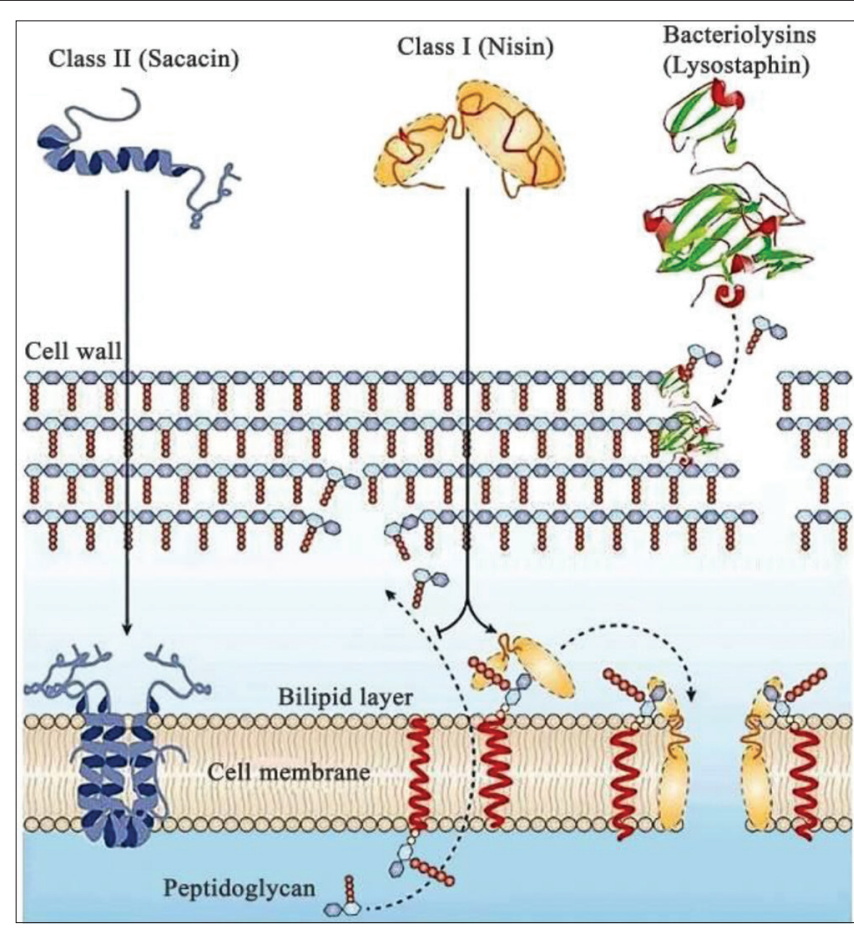

Figure 1: The mechanism of action of bacteriocins

kinds of bacteriocins are capable of forming lactic acid bacteria [37], [38], [39].

The practical use of bacteriocins is in the treatment of infectious diseases. They are also used as preservatives of food and fodder products.

In this regard, the selection, study of the properties and synthesis of new antibacterial and fungicidal antibiotics formed by lactic acid bacteria and other antagonist microorganisms, as well as the study of the prospects for their use in the pharmaceutical industry is of fundamental and practical interest.

The purpose of this work is screening and characterization of antagonistic properties of microorganisms isolated from natural sources in connection with the creation of new pharmaceutical substances.

\section{Objectives}

The objectives are as follows:

Isolation of lactic acid bacteria and other antagonist microorganisms from natural sources: soil, water bodies, and plant objects; Study of antimicrobial properties of lactic acid bacteria and other antagonistic microorganisms isolated from natural sources on solid and liquid nutrient medium;

Selection of strains with maximum antimicrobial properties for further research. 


\section{Research Objects and Methods}

The soil, water bodies, and plant objects of various municipal districts of the Kemerovo region: Kemerovo, Prokopevsky, Mariinsky, Yaysky, and Guryevsky served as a material for the isolation of microorganisms.

Soil sampling was performed 3 times. Samples were selected in a checkerboard pattern, diagonally, through the envelope at a specific depth or horizon. A shovel, scoop, knife, and soil drill were used for soil sampling. Each object before taking a separate sample was thoroughly cleaned, wiped with a cotton swab with alcohol and burned. Samples were taken in sterile kraft paper.

Isolation of strains from soil samples was carried out according to standard methods described in the "Methods of microbiological soil control. Methodical recommendations" (app. Chief state sanitary doctor of the Russian Federation 24.12.2004 № TC/4022) as well as a workshop on soil biology edited by G. M. Zenova.

Bacterial cultures of microorganisms were grown for $48 \mathrm{~h}$ on dense nutrient media of the following composition:

- $\quad$ Agar GRM, g/l: acid hydrolysate of fish meal 20, 0; glucose - 10, 0; and agar-agar - 15, 0;

Meat-peptone agar (MPA), g/l: dry enzymatic pepton - 10, 0; meat extract - 11, $0 ; \mathrm{NaCl}-$ 5, 0; agar-agar - 15, 0; and glucose - 10, 0; distilled water.

Identification of the isolated microorganisms was carried out using the methods proposed in the determinant of Berga bacteria and in the monograph by Nesterenko et al. Smears were stained with gram.

Cultural and morphological properties of isolates were examined using conventional microbiological methods, recorded the color, size, texture of the colonies in a dense environment, carried out staining smears for the Gram-stain, evaluated the motility of the cells in the preparation "crushed drop."

Evaluation of antimicrobial properties of lactic acid bacteria and other antagonistic microorganisms isolated from natural sources of the Kemerovo region was carried out in two ways: Diffusion method and method of determining the antagonistic activity in the liquid nutrient medium by optical density (OD).

used:

The following pathogenic test strains were

Escherichia coli ATCC 25922; Salmonella enterica ATCC 14028; Staphylococcus aureus ATCC 25923; Pseudomonas aeruginosa B6643; Bacillus mycoides EMTC; Alcaligenes faecalis EMTC 1882; Proteus vulgaris ATCC 63; Shigella flexneri ATCC 12022; Listeria monocytogenes ATCC 7644; Candida albicans EMTC 34; Aspergillus flavus ATCC 9643; and Penicillium citrinum ATCC 9849.
Cultivation of test strains of microorganisms.

Strain E. coliATCC 25922 cultured on a nutrient medium composition: trypton $-10 \mathrm{~g}$, yeast extract -5 $\mathrm{g}$, sodium chloride $-10 \mathrm{~g}$, and water $-1 \mathrm{I}$. $\mathrm{pH}$ 7.5-8.0. The Cultivation temperature is $37^{\circ} \mathrm{C}$.

S. enterica ATCC 14028 strain was cultured on the nutrient medium of the composition: Peptic digestion of animal tissue $-10 \mathrm{~g}$, meat extract $-5 \mathrm{~g}$, glucose -5 $\mathrm{g}$, sodium hydrophosphate $-4 \mathrm{~g}$, iron sulfate $-0.3 \mathrm{~g}$, bismuth sulfite $-8 \mathrm{~g}$, diamond green $-0.025 \mathrm{~g}$, agar $20 \mathrm{~g}$, and water $-1 \mathrm{I}$. $\mathrm{pH}$ of the medium 7.5-7.9. The culture temperature is $35^{\circ} \mathrm{C}$.

Strain of S. aureus ATCC 25923 was cultured on the nutrient medium of the composition: Casein hydrolysate $-10 \mathrm{~g}$, yeast extract $-2.5 \mathrm{~g}$, gelatin $-30 \mathrm{~g}$, D-mannitol - $10 \mathrm{~g}$, sodium chloride - $55 \mathrm{~g}$, ammonium sulfate - $75 \mathrm{~g}$, potassium hydrophosphate $-5 \mathrm{~g}$, agar $-15 \mathrm{~g}$, and water $-1 \mathrm{I}$. $\mathrm{pH}$ of the medium 6.8-7.2. The cultivation temperature is $30^{\circ} \mathrm{C}$

Strain $P$. aeruginosa B6643 was cultured on the nutrient medium composition: Meat water $-1 \mathrm{I}, \mathrm{NaCl}$ - $5 \mathrm{~g}$, pepton $-10 \mathrm{~g}$, and $\mathrm{pH}$ 6.8-7.0. The cultivation temperature is $37^{\circ} \mathrm{C}$

Strain B. mycoides EMTC 9 was cultured on the nutrient medium of the composition: Casein hydrolysate - $10 \mathrm{~g}$, yeast extract $-2.5 \mathrm{~g}$, glucose $5 \mathrm{~g}$, potassium hydrophosphate $-2.5 \mathrm{~g}$, agar-agar $3 \mathrm{~g}$, and water $-1 \mathrm{I}$. $\mathrm{pH}$ of the medium 7.2-7.6. The cultivation temperature is $30^{\circ} \mathrm{C}$.

The strain of $A$. faecalis EMTC 1882 was cultured on the nutrient medium of the composition: Special pepton - $10 \mathrm{~g}$, sodium chloride $-5 \mathrm{~g}$, sodium azide $-0.3 \mathrm{~g}$, chromogenic mixture $-0.06 \mathrm{~g}$, twin $80-2$ $\mathrm{g}$, sodium hydrophosphate $-1.25 \mathrm{~g}$, agar - $15 \mathrm{~g}$, and water $-1 \mathrm{I}$. $\mathrm{pH}$ of the medium 7.3-7.5. The cultivation temperature is $37^{\circ} \mathrm{C}$

Strain $P$. vulgaris ATCC 63 was cultured on the nutrient medium of the composition: Pepton -8 $\mathrm{g}$, sodium chloride $-5 \mathrm{~g}$, sodium deoxycholate $-1 \mathrm{~g}$, chromogenic mixture $-1.5 \mathrm{~g}$, propylene glycol - 10.5 $\mathrm{g}$, agar-agar - $15 \mathrm{~g}$, and water - $1 \mathrm{l}$. $\mathrm{pH} 7.1-7.5$. The cultivation temperature is $37^{\circ} \mathrm{C}$

Strain S. flexneri ATCC 12022 cultured on a nutrient medium composition: Peptic digestion of animal tissue $-5 \mathrm{~g}$, meat extract $-5 \mathrm{~g}$, lactose $-10 \mathrm{~g}$, a mixture of bile acids $-8.5 \mathrm{~g}$, sodium citrate $-10 \mathrm{~g}$, sodium thiosulfate $-8.5 \mathrm{~g}$, iron citrate $-1 \mathrm{~g}$, diamond green $-0.00033 \mathrm{~g}$, neutral red $-0.025 \mathrm{~g}$, agar $-15 \mathrm{~g}$, and water $-1 \mathrm{I}$. $\mathrm{pH}$ environment 6.8-7.2. The cultivation temperature is $37^{\circ} \mathrm{C}$.

The strain of L. monocytogenes ATCC 7644 was cultured on the nutrient medium of the composition: Peptic digestion of animal tissue $-23 \mathrm{~g}$, starch $-1 \mathrm{~g}$, sodium chloride $5 \mathrm{~g}$, D-mannitol - $10 \mathrm{~g}$, iron ammonium citrate $-0.5 \mathrm{~g}$, esculin $-0.8 \mathrm{~g}$, glucose $-0.5 \mathrm{~g}$, lithium chloride $-15 \mathrm{~g}$, phenolic red $-0.08 \mathrm{~g}$, agar $-13 \mathrm{~g}$, 
and water - $1 \mathrm{I}$. $\mathrm{pH}$ of the medium 6.8-7.2. The culture temperature is $35^{\circ} \mathrm{C}$.

Strain C. albicans EMTC 34 was cultured on the nutrient medium composition: Glucose - $20 \mathrm{~g}$, pepton $-10 \mathrm{~g}$, yeast extract $-5 \mathrm{~g}$, and water $-1 \mathrm{I}$. The temperature of cultivation is $30^{\circ} \mathrm{C}$.

Strain A. flavus ATCC 9643 was cultured on the nutrient medium of sucrose $-30 \mathrm{~g}$, sodium nitrate - $2 \mathrm{~g}$, potassium hydrophosphate - $1 \mathrm{~g}$, magnesium sulfate $-0.5 \mathrm{~g}$, potassium chloride $-0.5 \mathrm{~g}$, iron sulfate $-0.01 \mathrm{~g}$, agar $-15 \mathrm{~g}$, and water $-1 \mathrm{l}$. $\mathrm{pH}$ of medium 7.1-7.5. The cultivation temperature is $30^{\circ} \mathrm{C}$

Strain of $P$. citrinum ATCC 9849 was cultured on the nutrient medium of dextrose $-40 \mathrm{~g}$, a mixture of peptic digestion of animal tissue and pancreatic casein hydrolyzate (1:1) - $10 \mathrm{~g}$, agar-agar - $15 \mathrm{~g}$, and water $-1 \mathrm{I}$. $\mathrm{pH}$ of the medium 5.4-5.8. the cultivation temperature is $30^{\circ} \mathrm{C}$.

Table 1: Morphological properties of isolates from soils, water bodies, and plant objects of the Kemerovo region

\begin{tabular}{lllll}
\hline Sample, No & Indicator & & & \\
\cline { 2 - 5 } & Sporulation & Motility & Form & Gram-stain \\
\hline Isolate No 1 & - & + & Rod-shaped & Gram-negative \\
Isolate No 2 & - & + & Yeast-like fungi & - \\
Isolate No 3 & + & - & Yeast-like fungi & Gram-positive \\
Isolate No 4 & + & + & Rod-shaped & Gram-positive \\
Isolate No 5 & - & - & Yeast-like fungi & - \\
Isolate No 6 & + & - & Spherical & Gram-positive \\
Isolate No 7 & + & + & Rod-shaped & Gram-positive \\
Isolate No 8 & - & - & Spherical & Gram-positive \\
Isolate No 9 & + & + & Spherical & Gram-positive \\
Isolate No 10 & - & - & Spherical & Gram-positive \\
Isolate No 11 & - & - & Spherical & Gram-positive \\
Isolate No 12 & - & - & Rod-shaped & Gram-positive \\
Isolate No 13 & - & - & Rod-shaped & Gram-positive \\
Isolate No 14 & - & + & Rod-shaped & Gram-negative \\
Isolate No 15 & - & + & Rod-shaped & Gram-negative \\
Isolate No 16 & - & - & Spherical & Gram-positive \\
Isolate No 17 & - & + & Rod-shaped & Gram-negative \\
Isolate No 18 & + & - & Rod-shaped & Gram-positive \\
Isolate No 19 & + & + & Rod-shaped & Gram-positive \\
Isolate No 20 & + & + & Rod-shaped & Gram-positive \\
\hline
\end{tabular}

For work, a suspension of night broth crops grown on standard nutrient media was taken. The number of microorganisms (titer) in the suspension was determined by the OD at a wavelength of $595 \mathrm{~nm}$.

\section{Research Results and Discussion}

\section{Isolation of lactic acid bacteria and} other antagonistic microorganisms from natural sources: Soil, water bodies, and plant objects

As a result of the research, 20 isolates, different in morphological (Table 1) and phenotypic characteristics, were isolated from soils, reservoirs, and plant objects of the Kemerovo region (Table 2).

Preliminary analysis of phenotypic and morphological characteristics suggests the presence of the following genera in the analyzed samples: Bacillus, Leuconostoc, Pediococcus, Lactobacillus, and Bacteroides. The results of the identification of microorganisms isolated from natural objects of the Kemerovo region, based on the study of their cultural and morphological properties will be supplemented after genetic analysis, as well as the study of biochemical characteristics and antibiotic resistance.

Study of antimicrobial properties of lactic acid bacteria and other antagonistic microorganisms isolated from natural sources on solid and liquid nutrient media; selection of strains with maximum antimicrobial properties for further research

Table 2: Phenotypic properties of isolates isolated from soils, water bodies, and plant objects of the Kemerovo region

\begin{tabular}{|c|c|c|c|c|c|c|c|}
\hline \multirow[t]{2}{*}{ Isolate } & \multicolumn{7}{|l|}{ Indicator } \\
\hline & Nature of the edge contour & Profile & Surface & Color & Structure & Consistency & Transparency \\
\hline \multicolumn{8}{|c|}{ Soil of Kemerovo region (Pesherka village) } \\
\hline Isolate No 1 & Even & Flat & Smooth & Light yellow & Homogeneous & Dense & Transparent \\
\hline Isolate No 2 & Even & Waved & Small wrinkled & White & Homogeneous & Dense & Mat \\
\hline \multicolumn{8}{|c|}{ Soil of Prokopyevsky District (Kara-Chumysh village) } \\
\hline Isolate No 3 & Uneven & Convex & Hairy & From white to brownish green & Heterogeneous & Dense & Mat \\
\hline Isolate No 4 & Uneven & Convex & Smooth & Greyish white & Heterogeneous & Viscous & Mat \\
\hline \multicolumn{8}{|c|}{ Rhizosphere of plants of the Mariinsky District (Suslovo village) } \\
\hline Isolate No 5 & Even & Waved & Furrowed & Greyish white & Heterogeneous & Dense & Mat \\
\hline \multicolumn{8}{|c|}{ Rhizosphere of plants of the Yaysky district (Voznesenka village) } \\
\hline Isolate No 6 & Uneven & Waved & Small wrinkled & From white to cream & Homogeneous & Dense & Mat \\
\hline Isolate No 7 & Uneven & Flat & Smooth & Greyish white & Heterogeneous & Viscous & Mat \\
\hline Isolate No 8 & Even & Convex & Smooth & Grey & Homogeneous & Soft & Transparent \\
\hline \multicolumn{8}{|c|}{ Rhizosphere of plants from Guryevsky district (Ursk settlement) } \\
\hline Isolate No 9 & Uneven & Convex & Smooth & White & Homogeneous & Soft & Transparent \\
\hline Isolate No 10 & Even & Convex & Smooth & Orange green & Granular & Dense & Mat \\
\hline \multicolumn{8}{|c|}{ Plant wastes of JSC "Sukhovsky" (Kemerovo) } \\
\hline Isolate No 11 & Even & Convex & Rough & Skin & Homogeneous & Dense & Mat \\
\hline Isolate No 12 & Even & Flat & Smooth & White & Homogeneous & Dense & Mat \\
\hline \multicolumn{8}{|c|}{ Plant waste LLC Niva (Guryevsky district, and Gorskino settlement) } \\
\hline Isolate No 13 & Even & Flat & Smooth & White & Homogeneous & Dense & Mat \\
\hline Isolate No 14 & Even & Convex & Rough & Gray white & Granular & Dense & Translucent \\
\hline \multicolumn{8}{|c|}{ Plant waste of LLC "Veles" (Yaysky district, and Yaya settlement) } \\
\hline Isolate No 15 & Even & Convex & Plicated & Gray white & Homogeneous & Soft & Mat \\
\hline Isolate No 16 & Uneven & Convex & Rough & Skin & Homogeneous & Soft & Mat \\
\hline \multicolumn{8}{|c|}{ Bottom sediments of Lake Urskoye (Guryevskiy district) } \\
\hline Isolate No 17 & Even & Flat & Fine-grained & Yellowish & Homogeneous & Dense & Transparent \\
\hline Isolate No 18 & Even & Flat & Shiny & Cream & Granular & Soft & Mat \\
\hline \multicolumn{8}{|c|}{ Bottom sediments of the Kara-Chumysh reservoir (Prokopyevsky district) } \\
\hline Isolate No 19 & Even & Convex & Shiny & White & Homogeneous & Pasty & Translucent \\
\hline \multicolumn{8}{|c|}{ Bottom sediments of Lake Uday (Mariinsky District) } \\
\hline Isolate No 20 & Even & Flat & Shiny & White & Homogeneous & Soft & Mat \\
\hline
\end{tabular}



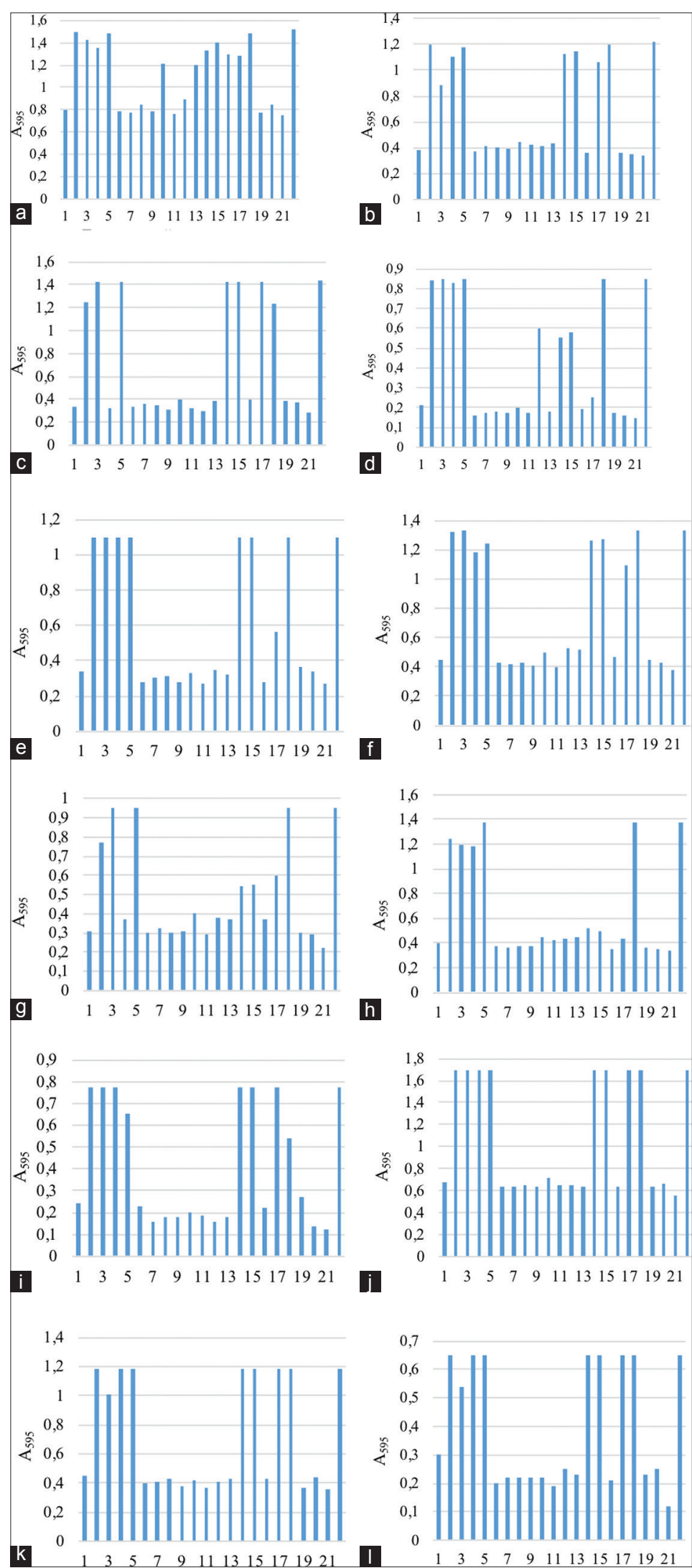

Figure 2: Results of the determination of antimicrobial activity of microorganisms isolated from natural sources of Kemerovo region in liquid nutrient medium: 1-20 - isolates 1-20, 21 - ciprofloxacin, 22 - control. Tested microorganism - (a) Escherichia coli ATCC 25922, (b) Salmonella enterica ATCC 14028, (c) Staphylococcus aureus ATCC 25923, (d) Pseudomonas aeruginosa B6643, (e) Bacillus mycoides ЭMTK 9, (f) Alcaligenes faecalis ЭMTK 1882, (g) Proteus vulgaris ATCC 63, (h) Shigella flexneri ATCC 12022, (i) Listeria monocytogenes ATCC 7644, (j) Candida albicans EMTK 34, (k) A. flavus ATCC 9643, (I) Penicillium citrinum ATCC 9849 


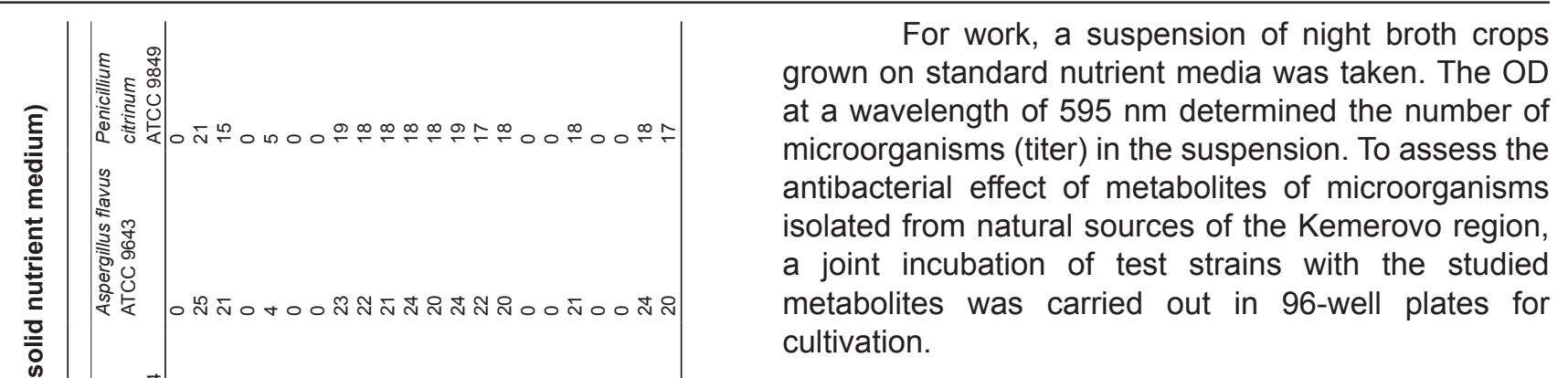

An analysis of the data presented in Table 3 and Figure 2 led to the following conclusions. From 20 tested microorganisms, 12 isolates (Isolate 1, Isolate 6 , Isolate 7 , Isolate 8 , Isolate 9 , Isolate 10 , Isolate 11 , Isolate 12 , Isolate 13 , Isolate 16 , Isolate 19 , and Isolate 20 ) show high antimicrobial activity against all test strains pathogenic and conditionally pathogenic microorganisms. For strains Isolate 14, Isolate 15, and Isolate 17, there was a slight antimicrobial activity against Gram-negative test strains, while Isolate 18 has an inhibitory effect only on Grampositive species. Isolate 2 has a slight antimicrobial effect on S. aureus, Proteus vulgaris, S. flexneri; Isolate 3 - test strains E. coli, S. enterica, S. flexneri, A. flavus, and $P$. citrinum; and Isolate 5 - test strains Alcaligenes faecalis and $L$. monocytogenes.

Thus, for further studies, the following isolates showing maximum antimicrobial activity against pathogenic and conditionally pathogenic test strains were selected: Isolate 1 , Isolate 6 , Isolate 7 , Isolate 8 , Isolate 9 , Isolate 10 , Isolate 11 , Isolate 12 , Isolate 13 , Isolate 16, Isolate 19, and Isolate 20.

\section{Conclusion}

The following results are obtained:

- $\quad$ Lactic acid bacteria and other microorganismsantagonists from natural sources were isolated: Soil, water bodies, and plant objects; 20 isolates were isolated, their cultural and morphological properties were studied; isolated microorganisms were found to belong presumably to the genera Bacillus, Leuconostoc, Pedio-coccus, Lactobacillus, and Bacteroides;

- $\quad$ Antimicrobial properties of lactic acid bacteria and other antagonistic microorganisms isolated from natural sources on solid and liquid nutrient media were studied;

- 12 strains of 20 isolates with maximum antimicrobial properties were selected for further studies.

Further research on the biochemical properties of lactic acid bacteria and other antagonist microorganisms isolated from natural sources, the study of antibiotic resistance of lactic acid bacteria and other antagonist microorganisms isolated from natural sources, as well as 
other more detailed studies will be conducted with selected 12 strains with maximum antimicrobial properties.

\section{Acknowledgments}

Financial support for the research was provided by the Ministry of Education and Science of the Russian Federation as part of the implementation of the Federal Target Program "Research and Development in Priority Areas of the Scientific and Technological Complex of Russia for 2014-2020", the grant agreement No. 07515-2019-1383 dated June 18, 2019 (unique project identifier RFMEFI57418X0207).

\section{References}

1. Abaturov AE, Kryuchko TA. The potential value of bacteriocins in the etiological treatment of infectious diseases of the respiratory tract. Zdorovie Rebenka. 2017;12(7):812-9. https:// doi.org/10.22141/2224-0551.12.7.2017.116187

2. Bisenova GN, Sarmurzina ZS, Almagambetov KK. The study of the bacteriocin-producing activity of isolates and collection cultures of lactic acid bacteria. Kazakhstan Sci News. 2016;1(127):86-98

3. Kuznetsova MV, Maslennikova IL, Žgur-Bertok D, Strain ŽP. Conjugative gene transfer of bacteriocins a new mechanism of antimicrobial action of probiotic drugs. Bull Perm Sci Cent Ural Branch Russ Acad Sci. 2017;4:45-52. https://doi. org/10.7242/1998-2097/2017.4.7

4. Kuliev AA, Demnerova K, Abdullaeva UD. Comparison of the antimicrobial activity of various strains of bacteria of the genus Lactobacillus against a number of pathogenic bacteria. Actual Probl Humanit Natl Sci. 2017;1(1):41-4.

5. Polyanskaya IS, Stoyanova LG, Semenikhina VF. Antagonistic activity of probiotic strains: Regulatory factors. Dairy Ind. 2017;1:42-4

6. Dyshlyuk LS, Asyakina LK, Sukhikh SA, Noskova SY. Analysis of the physico-chemical properties of the recombinant antimicrobial peptide. In: Materials of the 14th International Research and Practice Conference. Westwood: Science, Technology and Higher Education; 2017. p. 87-92.

7. Gaspar C, Donders GG, Palmeira-de-Oliveira R, Queiroz JA, Tomaz C, Martinez-de-Oliveira J, et al. Bacteriocin production of the probiotic Lactobacillus acidophilus ks400. AMB Express. 2018;8(1):153. https://doi.org/10.1186/s13568-018-0679-z PMid:30264211

8. Ghequire MG, Öztürk B, de Mot R. Lectin-like bacteriocins. Front Microbiol. 2018;9:2706. https://doi.org/10.3389/ fmicb.2018.02706 PMid:30483232

9. Abdullaeva NF. Modern views on the mechanism of action of bacteriocins of lactic acid bacteria (review). Actual Probl Humanit Natl Sci. 2014;10:23-27.

10. Vasilchenko AS, Vasilchenko AV, Valyshev AV, Rogozhin EA. A novel high-molecular-mass bacteriocin produced by: Enterococcus faecium: Biochemical features and mode of action. Probiotics Antimicrob Proteins. 2018;10(3):427-34. https://doi.org/10.1007/s12602-018-9392-0

PMid:29423898

11. Ankaiah D, Palanichamy E, Antonyraj CB, Ayyanna R, Perumal V, Ahamed $\mathrm{Sl}$, et al. Cloning, overexpression, purification of bacteriocin enterocin-b and structural analysis, interaction determination of enterocin-a, b against pathogenic bacteria and human cancer cells. Int J Biol Macromol. 2018;116:502-12. https://doi.org/10.1016/j.ijbiomac.2018.05.002 pmid:29729340

12. Goyal C, Malik RK, Pradhan D. Purification and characterization of a broad spectrum bacteriocin produced by a selected Lactococcus lactis strain 63 isolated from Indian dairy products. J Food Sci Technol. 2018;55(9):3683-92. https://doi.org/10.1007/ s13197-018-3298-4

PMid:30150828

13. Neustroyev MP, Tarabukina NP, Stepanova AM, Maksimova AN. The bactericidal effect of bacterial strains of Bacillus subtilis to leptospirosis pathogens. Rep Russ Acad Agric Sci. 2015;4:63-5.

14. Drider D, Bendali F, Naghmouchi K, Chikindas ML. Bacteriocins: Not only antibacterial agents. Probiotics Antimicrob Proteins. 2016;8(4):177-82. https://doi.org/10.1007/s12602-016-9223-0 PMid:27481236

15. Hegarty JW, Guinane CM, Ross RP, Hill C, Cotter PD. Lack of heterogeneity in bacteriocin production across a selection of commercial probiotic products. Probiotics Antimicrob Proteins. 2017;9(4):459-65. https://doi.org/10.1007/s12602-017-9326-2 PMid:28942526

16. Mukherjee S, Ramesh A. Bacteriocin-producing strains of Lactobacillus plantarum inhibit adhesion of Staphylococcus aureus to extracellular matrix: Quantitative insight and implications in antibacterial therapy. J Med Microbiol. 2015;64(12):1514-26. https://doi.org/10.1099/jmm.0.000181 PMid:26445850

17. Lozo J, Mirkovic N, O'connor PM, Malesevic M, Miljkovic M, Polovic N, et al. Lactolisterin BU, a novel class ii broad-spectrum bacteriocin from Lactococcus lactis subsp. Lactis bv. diacetylactis bgbu1-4. Appl Environ Microbiol. 2017;83(21):e01519. https:// doi.org/10.1128/aem.01519-17 PMid:28842543

18. El-Arabi NI, Salim RG, Abosereh NA, Abdelhadi A. Molecular characterization of some antilisterial bacteriocin genes from Enterococcus faecium and Pediococcus pentosaceus. Microbiol Biotechnol Lett. 2018;46(3):288-99. https://doi.org/10.4014/ mbl.1803.03001

19. Acedo JZ, Chiorean S, Vederas JC, Van Belkum MJ. The expanding structural variety among bacteriocins from grampositive bacteria. Fems Microbiol Rev. 2018;42(6):805-28. https://doi.org/10.1093/femsre/fuy033 PMid:30085042

20. Dicks LM, Dreyer L, Smith C, van Staden AD. A review: The fate of bacteriocins in the human gastro-intestinal tract: Do they cross the gut-blood barrier? Front Microbiol. 2018;9:2297. https://doi.org/10.3389/fmicb.2018.02297

21. Baindara P, Korpole S, Grover V. Bacteriocins: Perspective for the development of novel anticancer drugs. Appl Microbiol Biotechnol. 2018;102(24):10393-408. https://doi.org/10.1007/ s00253-018-9420-8 PMid:30338356

22. Mokrushina OS, Andreeva IS, Mazurkova NA, Puchkova I. Antagonistic properties of the strain of Bacillus thuringiensis ssp. galleriae AK-4 isolated from sedimentary rocks of Lake Baikal. Int Res J. 2013;81(15):74-7.

23. Kazachina AD. Actual aspects of biotechnological development of experimental samples of lantibiotics. J Sci Articles Health Educ 2015;17(3):57-66. 
24. Nandan PK, Nagar A. Isolation and identification of bacteriocin producing microbes using biochemical and molecular tools and analysis of its biopreservation potential. Asian J Pharm Clin Res. 2016;9:278-82. https://doi.org/10.22159/ajpcr.2016.v9s3.15043

25. Escamilla-Martínez EE, Cisneros YM, Fernández FJ, QuirascoBaruch M, Ponce-Alquicira E. Identification of structural and immunity genes of a class IIB bacteriocin encoded in the enterocin a operon of Enterococcus faecium strain MXVK29. J Food Prot. 2017;9:1851-6. https://doi.org/10.4315/0362-028x. jfp-17-039 PMid:28990822

26. Farías ME, Farías $\mathrm{RN}$, de Ruiz Holgado AP, Sesma F. Purification and n-terminal amino acid sequence of enterocin CRL 35, a "pediocin-like" bacteriocin produced by Enterococcus faecium CRL 35. Lett Appl Microbiol. 1996;22(6):417-9. https:// doi.org/10.1111/j.1472-765x.1996.tb01193.x PMid:8695065

27. Ishibashi N, Zendo T, Koga S, Shigeri Y, Sonomoto K. Molecular characterization of the genes involved in the secretion and immunity of lactococcin q, a two-peptide bacteriocin produced by Lactococcus lactis qu 4. Microbiology. 2015;161(11):2069-78. https://doi.org/10.1099/mic.0.000157 PMid:26306611

28. Lim ES. Purification and characterization of two bacteriocins from Lactobacillus brevis BK11 and Enterococcus faecalis BK61 showing anti-Helicobacter pylori activity. J Korean Soc Appl Biol Chem. 2015;58(5):709-14. https://doi.org/10.1007/ s13765-015-0094-y

29. Cao S, Du R, Zhao F, Xiao H, Zhou Z. The mode of action of bacteriocin CHQS, a high antibacterial activity bacteriocin produced by Enterococcus faecalis TG2. Food Control. 2019;96:470-8. https://doi.org/10.1016/j.foodcont.2018.09.028

30. Abdullaeva NF. General understanding of the mechanisms of heterologous production of lactic acid bacteria bacteriocins (review). Actual Probl Humanit Natl Sci. 2016;1(1):29-32.

31. Prosekov AY, Dyshlyuk LS, Milentyeva IS, Sykhikh SA, Babich OO,
Ivanova SA, et al. Antioxidant and antimicrobial activity of bacteriocin-producing strains of lactic acid bacteria isolated from the human gastrointestinal tract. Prog Nutr. 2017;19(1):67-80.

32. Vasilchenko AS, Valyshev AV. Optimization of the composition of the nutrient medium of microorganisms as an approach to the isolation of bacteriocins. Bull Orenburg State Univ. 2017;12(212):84-9.

33. Sidorova TM, Asaturova AM, Khomyak Al. Biologically active metabolites of Bacillus subtilis and their role in the control of phytopathogenic microorganisms. Agric Biol. 2018;53(1):29-37.

34. Morton JT, Freed SD, Lee SW,. A large scale prediction of bacteriocin gene blocks suggests a wide functional spectrum for bacteriocins. BMC Bioinformatics. 2015;16(1):381. https://doi. org/10.1186/s12859-015-0792-9

35. Lenchenko EM, Khu B, Lomova YV. Research of antagonistic properties and sensitivity of microorganisms to antibacterial drugs. Agric Sci. 2017;6:17-22.

36. Sultimova TD, Zakharov EV. Bacteriocins of lactic acid bacteria Bull VSGUTU. 2016;2(59):41-7.

37. Boyanova L, Gergova G, Markovska R, Yordanov D, Mitov I. Bacteriocin-like inhibitory activities of seven Lactobacillus delbrueckii subsp. Bulgaricus strains against antibiotic susceptible and resistant helicobacter pylori strains. Lett Appl Microbiol. 2017;65(6):469-74. https://doi.org/10.1111/lam.12807 PMid:28975642

38. Daba GM, Ishibashi $N$, Gong $X$, Taki $H$, Yamashiro $K$, Lim YY, et al. Characterisation of the action mechanism of a Lactococcus-specific bacteriocin, lactococcin Z. J Biosci Bioeng. 2018;126(5):603-10. https://doi.org/10.1016/j. jbiosc.2018.05.018 PMid:29929768

39. Gopakumaran N, Veerasangili SG, Valliaparambal PT. Isolation and characterization of bacteriocins like antimicrobial compound from Lactobacillus delbrueckii subsp lactis. Jordan J Biol Sci. 2017;10(4):221-7. 